SCIENTIFIC RESEARCH 



\title{
PUBLIC RELATIONS AND THE MILITARY - EVALUATION OF THE SLOVENIAN ARMED FORCES
}

\author{
Liliana BROŽı̌̌ \\ Ministry of Defence, Slovenian Armed Forces
}

\begin{abstract}
Public confidence in the armed forces as a national institution is of great significance and directly related to the conditions for its operation and, thus, the functioning of the state. Both wish to operate openly, transparently and in cooperation with civic society. The armed forces as a social institution can be maintained only if they fulfil the public's imperatives. In terms of the public and the media, a question arises regarding the balance between social and functional imperatives, the latter representing a fundamental mission of the armed forces.

We wanted to know what public relations are like in the case of the Slovenian Armed Forces; how they are seen by internal and external stakeholders. Among the latter, we focused on the general public's opinion, the opinion of media representatives and the opinion of experts from academia. The findings derived from various projects in the period between 2010 and 2013 were the basis for determining orientations for the future.
\end{abstract}

Keywords: Public relations, armed forces, Slovenian Armed Forces, evaluation, projects, public opinion.

\section{Introduction}

According to the research of the Centre for Public Opinion Research (CJM), since Slovenia's gaining of independence, the Slovenian Armed Forces (SAF) have been achieving relatively high marks on the scale of Slovenian public confidence in 
public institutions. Public confidence in the armed forces as a national institution is of great significance and directly related to the conditions for its operation. The general public and public policy makers are the target public, which may have some influence, but policy makers are also the ones deciding on the mission, operation, financing and future of the armed forces. All this affects the quality of performance, but in comparison with the external public, it also depends on the internal public in the armed forces. The internal public (or publics) in the Slovenian defence system includes all employees with different statuses, such as civilians (officials, professional and technical workers) and military personnel (soldiers, non-commissioned officers, officers and generals and military specialists) in various internal organisational units. The article will focus on the armed forces' employees.

Public confidence in state institutions is important in terms of the functioning of the state. In democratic societies, the latter wishes to act openly, transparently and in cooperation with civic society, with a view to achieving the best performance in carrying out its mission. The armed forces pertain to the repressive state bodies which carry out their mission very differently than other state institutions. This feature is also reflected in the use of arms and operations beyond national borders in international operations and missions in the environments and situations with high security threats. This requires more accountability of policy-makers who decide on such referrals, but also of the employees in the armed forces, which must be further trained and equipped for major potential threats in carrying out their mission. In this respect, public relations play an important role, which contributes to public information on the functioning of the armed forces and, at the same time, the trust in them.

Because of what was stated above, we were interested in the quality of the field work of public relations in the SAF. In the case of the SAF, it can be concluded from the Slovenian public confidence in public institutions that both the organisation and its employees perform their mission well. According to the CJM, their performance is even very good, since the level of confidence in the SAF remains relatively constant compared to the confidence in other public institutions, which has been decreasing. SAF public relations provide an image of the $\mathrm{SAF}^{1}$ for the

1 The public image of the SAF and, thus, the confidence of the public is influenced by each individual with their physical appearance and their actions both at work and in spare time. 
public. Measurements of Slovenian public opinion are just one of the indicators of the external quality of public relations in the armed forces; therefore, we also wanted to check other ways of assessing quality in this field, such as the internal public and media representatives, where we used the method of evaluation.

\section{Theory framework}

\section{Public Relations}

The concept of public relations is the result of the work of Edward L. Bernays ${ }^{2}$, who based his findings on two works of the $19^{\text {th }}$ century, namely those by Dorman B. Eaton ${ }^{3}$ (1882) and Hough Smith ${ }^{4}$ (1842). Bernays wrote that public relations "means exactly what it says, relations of an organisation, individual, idea, whatever, with the publics on which it depends for its existence." (Bernays 1986, p. 35, Verčič, 1995, p. 17)

Hallahan understands public relations as one of the six disciplines that make up the concept of communication management, while stressing that individual communication disciplines have a common purpose, while their goals and strategies are very similar. They differ mainly in tactics, desires of organisations regarding the coordination of communication, convergence of media, and the blurring of the boundaries between communication genres, forcing them to adapt to a changing environment. Furthermore, he states that organisations strive to achieve integration and better performance primarily through synergy and better efficiency and less with redundancies (Hallahan et al., 2008, p. 630). In addition to public relations, other disciplines include management, marketing, professional and political communication and information or social campaigns (ibid).

2 Edward Luis Bernays (1891-1995), born in Austria, lived in the United States. He is considered to be "the father of public relations". He brought together the findings of psychology and psychoanalysis set out by his uncle Sigmund Freud. According to the estimates of Life magazine, he is considered one of the hundred most influential people of the $20^{\text {th }}$ century.

3 Author of the book The Public Relations and Duties of the Legal Profession.

4 Author of the book The Theory and Regulation of Pubic Sentiment. 
The World Assembly of Public Relations Associations has defined these relations as "/.../ the art and social science of analysing trends, predicting their consequences, counselling organisational leaders, and implementing planned programmes of action, which will serve both the organisation and the public interest." (Verčič, 1999, p. $520-521)$

According to the SAF spokesman, Simon Korez, "if we want to fulfil the mission of the profession, as defined by one of the many definitions, it is necessary to manage public relations in a strategic manner, with the help of sophisticated planning, attentive management activities and continuous research and evaluation of the effects of communication. Opting for individual and ad hoc activities cannot provide an effective and efficient communication." (Korez 2008, p. 58)

As Korez continues, the understanding of public relations is primarily related to the achievement of publicity in the media at any price. Relations with the media, such as those who pass on and design communication, are an important area of activity, but certainly not the only one.

Communication activities are thus not an end in themselves. Communicators manage them, in particular, to support the achievement of organisational business objectives. "The military community has the following objectives: the positive public image of the Slovenian Armed Forces; positive, but realistic promotion of the military profession (there should be no propaganda in the military community); support for commanders when deciding on the actions within command and control, and the preparation and management of communication strategies in support of the projects." (ibid)

\section{Evaluation in the field of public relations}

In Slovenian, the word evaluation means assessment and the assigning of value, while the English language ${ }^{5}$ dictionary explains it as conversion, the determination of value. In the literature, there is also a record of evaluation, but it is very rare.

5 In Cambridge Dictionaries Online, 29.6.2015. 
According to Paton, evaluation is a systematic collection, analysis and assessment of information on the activities, characteristics and results of the programmes in order to reduce uncertainty, increase performance and make decisions in accordance with the objectives and purposes of the programmes (Patton in Rihter, 2004, 91).

According to Bennet (2003, p. 14), the difference between the evaluation and research is that the research is aimed at understanding the phenomenon it investigates, while the evaluation focuses on the determination of the value and benefits of a project. Bennet understands research as more narrowly focused with more importance assigned to technical relevance, while evaluation is more comprehensive, with more importance assigned to usability and credibility. According to Serajnik, the results of the evaluation in the field of public relations contribute to a change - for the better or for the worse (abolishment of a programme or work), critical issues open up and the sensitivity of the involved parties increases (2008, p. 850).

In relation to the evaluation in the field of public relations, Rühl distinguishes three approaches: lay, professional and scholarly. In the lay approach, practitioners rely on sound judgment. They act, judge and evaluate on the basis of their experience and feelings. Experts, however, abide by professional formal (laws, codes, standards, etc.) and informal (morality, trust, responsibility, etc.) norms set and nourished by organisations. Measurements and evaluations are carried out by national and international associations in an organised manner. The academic world distinguishes between applicative and scientific research. The former aims to find practical solutions for strategic planning and action and is focusing on the professional practice of public relations, the design of forms and ways of conceptualisation, and the implementation of communication management in order to achieve performance and efficiency. Scientific research is significantly less present (Rühl 2008, p. 21-33).

Nevertheless, the key question here is what public relations can contribute at a social, organisational, functional, programming, project and individual level. In order to establish all of the above, research in the field of public relations is 
essential. Rühl's article ${ }^{6}$ defining three approaches to the evaluation of public relations served as our guideline in the evaluation of public relations in the SAF. It defines that the sociological view of public relations management as a functional system is especially based on the promotion and preservation of public interest and public confidence. The external aspect shows public relations as a system of daily persuasion of the public, while the internal aspect can be understood in two ways, namely as the practice of the profession and as a subdivision of communication with its research and theoretical bases (Rühl 2008, p. 21-33). Public relations cannot, therefore, be evaluated in financial terms, as their key results include public attention, professional work, moral principles, the rationality of information, promotion of new topics, balanced legislation and the confidence of the public and individuals (ibid).

Public opinion as an indicator of the quality of public relations in the armed forces

Public opinion is the most common expression of opinions, attitudes and moods of the public on matters of general interest argue Rus and Toš. Public opinion is only the final result; the prevailing or collective judgment is provided by the public in the opinion process and it is socially determined. According to the authors, it is the result of a dynamic and contradictory opinion process in the fundamental community plane, which is modified or even changed in further down the opinion process (2005, pp. 336-369).

Changes which affected the international security environment after the Cold War and 9/11 are also reflected in the armed forces and their relations with the public. Postmodern contemporary armed forces are characterised by the increasingly open character of military organisations in communication with the public, the exchange of information and access to them, in their increased media production, as well as in readiness for cooperation with the mass media (ibid).

6 Article Public Relations Methodology: Should we bother (If it exists)? in the monograph by Betteke, Tkalac Verčič and Verčič titled Public Relations Metrics: Research and Evaluations. 
The transformation of military communication of the military sphere has, in particular, been significantly affected by the following:

- Abolishment of conscription and shift to (fully) professional armed forces

- The impact of globalisation and modern communication technologies

- The process of democratisation and changing of the values, the increasing importance of human rights and prevention of critical requirements of the public (Van Dyke, Verčič, 2009).

In the previous century, the theoretical framework for exploring the role of the armed forces in relation to the general public was made by Huntington, later significantly upgraded by Edmonds, Jelušič and others. The essence of his argument is that the armed forces as a social institution can be maintained only if they meet public imperatives (Huntington, 1957). Armed forces and defence systems must be adapted to the requirements of the public, but these requirements are previously co-created by affecting the process of forming public opinion, argues Prezelj (1997, p. 1020). From the point of view of the public and the media, a question arises regarding the balance between meeting social and functional imperatives. The latter represents a fundamental mission of the armed forces, i.e. the defence of the country in relation to the social imperative, which is the result of ideologies, values and cultural norms (Jelušič, 1997, p. 68).

According to Prezelj, the more it seems that the military operates in the spirit of the set requirements, the more it is acceptable to the general and specific public. The acceptability of a specific government institution, however, is a prerequisite for achieving the loyalty of citizens and recognising its legitimacy (Prezelj, 1997, p. 21). Jelušič argues that the legitimacy of the security policy and the armed forces in a democratic society is subject to constant verification and influence. Legitimacy is not something firmly guaranteed, which would be achieved once and would last forever, but is repeatedly facing its fundamental problems. Again and again, it is exposed to public attention, criticism and control (1997, p. 171).

Korez confirms the theses of the above-listed authors and, at the same time, expresses the awareness of employees dealing with public relations in the armed forces by referring to the fact that those implementing communication strategies take into account public opinion when planning their work and try to influence it with various forms of proactive work. He specifically emphasises that public opinion is mainly expressed by the active public with firm and active opinions. 
However, an important part of public relations is also the inactive public, which becomes active when broad general issues are at stake. Thus, the armed forces without the support of the public cannot effectively perform any new tasks, whereby Korez specifically stresses the importance of public opinion in connection with the participation of the armed forces in international operations and missions (Korez 2008, p. 61).

\section{Methodological approach}

The Ministry of Defence has several organisational units, such as the Slovenian Armed Forces (SAF), the administrative part of the ministry, the Administration for Civil Protection and Disaster Relief (ACPDR) and others. Public relations are in the domain of the Strategic Communication Service, while the SAF and ACPDR have their own representatives for public relations. The SAF also has a special division for this purpose.

In order to establish the quality of public relations in the SAF, the Public Relations Division at the General Staff of the SAF carried out various projects in which we focused on the internal and external publics.

The term internal public refers to all the employees in the defence system, who with the help of various media monitor the developments within and outside the system. The Ministry has made available a special internal web portal called Infotočka (Info Point) through which it informs its employees about a wide range of topical issues and events on a daily basis. In addition, it includes regular sections on various legal acts, trade unions, sports, education and training and other areas. The SAF also communicates with its employees through several publications aimed at familiarising readers with various activities of individual units (Prvi (First) magazine, Prava smer (the Right Direction), Modri (Blue), military learning process (Vojaškošolski zbornik (Military Education Bulletin)) or individual subject areas (Vojaška zgodovina (Military History)).

External public is perceived as all those individuals, organisations or groups who are not employed in the defence system. The SAF communicates with the external public through various posts on SAF and MoD websites, the statements by the 
spokesperson and other employees, various publications, press conferences and other events for the media and specific target groups.

This is a target group that is much harder to identify and access for evaluation. Who are, therefore, those parts of the external public who can best evaluate the work in the field of public relations? According to our findings, they are the representatives of the media that more or less regularly cooperate with the SAF. In order to get a broader awareness, we have decided to pay more attention to the findings of the Centre for Research of Public Opinion, namely in measuring the confidence in Slovenian public institutions, with the emphasis on the SAF, and the interpretation of these results.

\begin{tabular}{|l|l|l|}
\hline $\begin{array}{l}\text { Approaches to evaluation } \\
\text { according to Rühl }\end{array}$ & Internal public & External public \\
\hline Lay approach & $\begin{array}{l}\text { Project 1: Internal web portal } \\
\text { INFOTOČKA (Info Point) }\end{array}$ & $\begin{array}{l}\text { Project 4: Public confidence in } \\
\text { the SAF }\end{array}$ \\
\hline Professional approach & $\begin{array}{l}\text { Project 2: Communication } \\
\text { with the SAF's internal public }\end{array}$ & $\begin{array}{l}\text { Project 3: Communication of the } \\
\text { SAF with media representatives } \\
\text { Project 4: Public confidence in } \\
\text { the SAF }\end{array}$ \\
\hline Scholarly approach & $\begin{array}{l}\text { Project 4: Public confidence in } \\
\text { the SAF }\end{array}$ \\
\hline
\end{tabular}

Table 1: Approaches to evaluation according to Rühl in connection with the SAF's individual projects in the field of public relations

\section{Project 1: Internal web portal INFOTOČKA (Info Point)}

The internal website of the MoD was renovated in 2009. There was a supplement added to the website, called Info Point, which is a communication tool or a portal for internal information of the SAF.

For the purpose of the evaluation, a questionnaire was distributed to the employees after the introduction of the Info Point in order to determine its usefulness, relevance and functionality, edit the corporate image and add new information sections or communication tools to maximise the expectations of SAF employees. 
The questionnaire was distributed to 530 SAF members, namely soldiers, noncommissioned officers and junior military specialists ${ }^{7}$ (which represent 10 per cent of the entire sample). The questionnaires were filled out in the period between 15 March and 15 April 2010.

\section{Project 2: Communication with SAF's internal public}

Evaluation of internal communication in the SAF was conducted in collaboration with the Pristop agency. The purpose of the questionnaire was:

- to obtain information about the media habits of officers in the SAF;

- to obtain an assessment of the current state of internal communication in the SAF;

- to identify the needs, wishes and expectations of officers associated with internal communication in the SAF;

- to find the biggest gaps in internal communication in the SAF, which would serve as the basis for its further management.

The questionnaire included three parts: assessment of internal communication in the SAF (how often the information on the SAF is searched for and where it is found; how these pieces of information are assessed; what the proposed improvements are), media consumption (which internal and external media are followed and how often; where to get the most information), and demographic information about the respondents.

The questionnaire was posted onine on http://surveymonkey.com/s/morsvprasalnik. Officers completed it in the period between 25 October and 10 November 2010. We received 210 completed questionnaires (about 17 per cent of all officers employed in the $\mathrm{SAF}^{8}$ ).

7 In 2010, there were some 5,300 of them.

8 In 2010, there were some 1,200 of them. 


\section{Project 3: Communication of the SAF with media representatives}

The questionnaire for media representatives was prepared with the aim to evaluate and improve the scope of work of public relations. It consisted of three components, namely the media and the SAF; cooperation of media representatives with SAF public relations officers, and visits of media representatives to international operations and missions organised by the SAF. The questionnaires were sent to media representatives and their editors in late December 2011 and early January 2012. The evaluation included all the questionnaires completed by the end of February 2012.

\section{Project 4: Public confidence in the SAF}

In collaboration with the Obramba magazine, a project was carried out with the aim of inviting a variety of experts in the field of public relations and obtaining their opinions on the Slovenian public confidence in the SAF in relation to the results of the CJM, which measures public confidence in public institutions several times a year.

The following responded to the invitation: a former employee of the Pristop agency, who participated in media campaigns together with the $\mathrm{SAF}^{9}$; two PhD-holders from the Chair of Defence Studies of the Faculty of Social Sciences in Ljubljana, and three journalists, who regularly and professionally monitor the activities of the SAF. All opinions were published in the Obramba magazine in July 2013, together with an interview with the SAF's spokesman.

9 In 2010, the SAF, together with the Pristop agency, received one of the Effie awards for marketing effectiveness. "Ponosni nase (Proud of Ourselves)" was a presentation with a fundamental objective to acquaint young people with the possibility of professional integration in the SAF. It was designed at a time of great economic growth when the labour market was intensively employing people, employable in the SAF. The SAF, together with the Ministry of Defence, selected the agency and prepared a comprehensive project aimed at soliciting young people for employment in the SAF. Because of this comprehensiveness, this was a special promotional campaign which had market efficiency (interview with Korez in the Obramba (Defence) magazine, July 2013). 
The concept of evaluation incorporated the holistic approach which we used to cover all those publics, who can in any way contribute to the evaluation of public relations in the SAF. In the first case, the target audience included soldiers, noncommissioned officers and junior military specialists; in the second case, officers and senior military specialists responded to the questionnaire; in the third case, representatives of major media companies and local journalists participated, and the fourth case incorporated the general lay public, which was included in the sample of respondents of the $\mathrm{CJM}^{10}$ survey, as well as those who deal with public relations professionally or academically. We have therefore tried to take into account, as far as possible, the different theoretical frameworks of Slovenian (Verčič, Serajnik Sraka etc.) and foreign authors (Bernays, Huntington, etc.) so that the evaluation would both contribute to the quality of the evaluation and realistic assessment of the situation, and at the same time provide guidance for future work. In terms of methodology, we based our work on the approaches to the evaluation according to Rühl (2008).

\section{Research}

\section{Info Point - results}

We received 605 completed questionnaires. 70 per cent of them were filled out by soldiers, 16 per cent by non-commissioned officers, 9.5 per cent by officers and 4 per cent by military specialists. In terms of corporate image, the Info Point was assessed with an average rating of 2.93; the organisation of sections with an average rating of 2.79; clarity with 2.81; functionality of content with an average rating of 2.78; topicality with an average rating of 2.8 ; the manner in which information is passed with 2.83, and usefulness with an average rating of 2.69 .

10 On average, samples include between 800 and 1,000 participants in each measurement separately. More on http://www.cjm.si/?q=PB_rezultati, 18 October 2013. 
Under the heading "your opinion", which included a blank space for suggestions, respondents suggested a great variety of proposals, which were very specific and referred to individual areas or units.

The answers to the question about the areas on which respondents would like to get more information were classified according to the expressed interest (multiple answers were possible). The greatest interest was attracted by the information related to the possibilities of promotion (363), the information on salaries (334), legal interpretations of the legislation (314), job opportunities in international operations and missions (299), military education and training (299), language courses within the e-learning system (274), military education and training abroad (266), leave of absence (266), job opportunities abroad (258) and, the last, on education in general (44).

Under the heading "your views and suggestions," the respondents would like to see more information on sporting events organised by or including the SAF; changes in the organisation of activities in the SAF and the MoD; various holiday opportunities; firing ranges; official SAF positions regarding media comments related to the SAF; training in the field of information technology; job vacancies in the SAF, MoD, in missions and abroad, and so on.

\section{The quality of internal communication in the SAF as seen by the employees}

The results of the survey, which was organised in cooperation with the Pristop agency, were presented to the SAF public relations personnel at their regular monthly meeting in April 2011 at Vrhnika. They were drawn up in two sections: the quality of internal communication in the SAF and the analysis of the media.

Most of the information is provided to the employees directly by their superiors. According to the Likert scale of 1 to 5 , this response received an average rating of 3.36. It was followed by information from the Info Point, which received a rating of 3.35.; information from colleagues was assigned the rating of 3.33, and information from the e-mail messages with 3.27. The fifth was the Revija Slovenska vojska (Slovenian Armed Forces magazine) with a rating of 2.67; the 
sixth was information provided by the second superior with a rating of 2.59 , and the seventh the Obramba magazine with a rating of 2.55 .

SAF publications as a source of information were rated in the following order: Bilten Slovenske vojske (Bulletin of the Slovenian Armed Forces) - 1.79, Prvi (First) - 1.44, Prava smer (Right direction) - 1.24; Častno in predano (With honour and diligence) - 1.20, and Ujma (Natural disaster) - 1.19.

When asked about the source of information, direct superiors received 52.2 per cent of possible responses "often" and "very often", other associates received 48 per cent, Info Point 53.2 per cent and emails 53.9 per cent.

When asked about the information they would like to know more about, the information on the functioning of other armed forces was selected most often with 75 per cent of respondents feeling that there was not enough information provided on this subject. Information on the promotions within the defence system was rated with 73.8 per cent, on other organisational units with 71 per cent, on the recruitment of new troops with 69.3 per cent, on the strategy, vision and goals of the defence system with 67.2 per cent, on the socially responsible functioning of the system 66.5 per cent, on the functioning of NATO 66.6 per cent, and so on.

When asked about the topics they would like to be more informed about, the employees most often chose correct information on the operation of the system (34.5 per cent). The second was the information on human resources (22.7 per cent), followed by information on the development of the SAF (21.8 per cent).

The respondents rated the publications as predominantly informative and rich in photo material. Regular issuing, a wide variety of authors and interviews were identified as strong points, while the respondents find the newsletters fairly static. The nature of information is considered very formal, non-dynamic or rigid. The content predominantly includes information on the organisation, but not enough information about the people and the profession; the sections are insufficiently diverse. The speakers mainly include high-ranked and senior employees. The language is "plain" and titles "tedious and merely informative."

The "Prvi" (First) magazine was highlighted as a good example of a newsletter. 
Key findings from the questionnaire are as follows:

- The effectiveness of internal communication tools is limited. They are available enough, but not fully utilised.

- In the system, there are two groups of employees. The first is the group of soldiers with a time-limited contract of employment. They are interested in the information about employment. They are younger than 36 years, have less than 11 years of service and are the least satisfied with internal communication. They are interested in younger-generation communication tools and most often seek information outside the system. The second group includes permanent employees, who, on average, have a higher education level, higher ranks and more seniority. Their expectations related to internal communication are much higher; they are more familiar with the organisation and the mission of the system; they use all communication tools, and are much more satisfied than the first group.

- Interpersonal communication is at a relatively high level. The communication with external actors, such as family members, friends and acquaintances, who help shape both internal and external communication between employees, is also very good.

- With regard to the group of tools, personal communication is the most used tool, followed by electronic and written communication, web pages, and internal newsletters in fifth place.

- As key weaknesses, the respondents highlighted internal communication, which is focused primarily on working instructions; there is no other content. The information is not timely and of high-quality, but rather inaccurate and misleading.

- As key improvements, the employees propose more informal communication (meetings with the leadership outside the workplace, leisure activities, etc.), improvement of the feedback system and upgraded IT tools.

- On a substantive level, the employees would want more information on human resources, defence-related strategic topics, more information of the events outside the SAF, and correct and prompt information. 


\section{The quality of SAF public communication in terms of media representatives}

We tried to determine how often the media follow the developments in the SAF. We established that 23 per cent of all those who have completed the questionnaire do so every day, 27 per cent once a week, 15 per cent once a month and 35 per cent occasionally.

When asked about their biggest source of information about the SAF, various on-line sources were placed first; next were official SAF public relations representatives, the third were radio, television and newspapers, and the fourth the SAF's and MoD's official websites. When asked whether the media provide sufficient information to the Slovenian public about the mission and functions of the SAF, on topical events and assignments abroad, 54 per cent of respondents replied positively and 46 per cent negatively.

Quality information on the SAF, which appears in publicly, was assessed according to individual criteria, as shown in Figure 1.
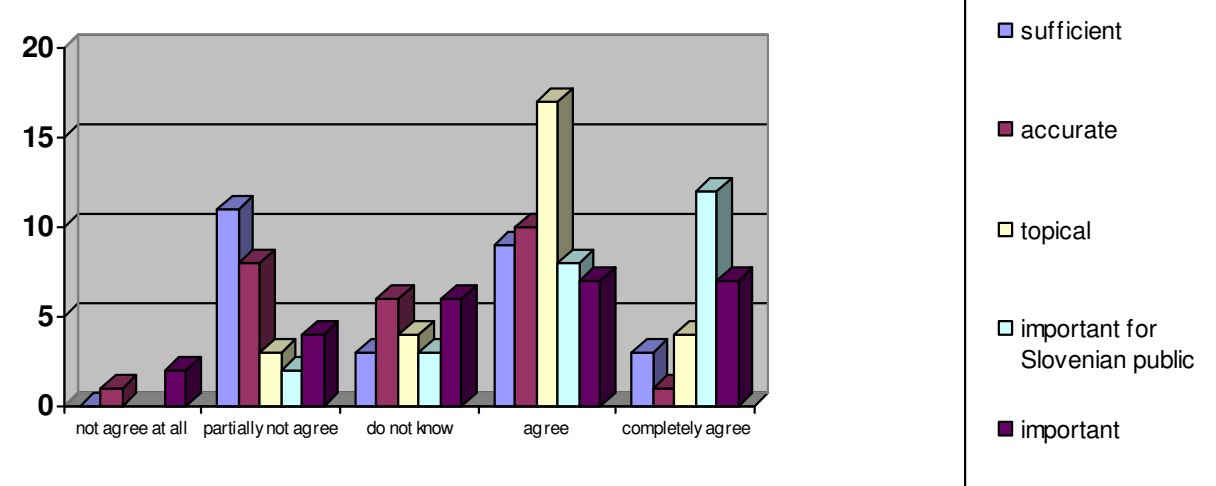

Figure 1: Reply to a question about the quality of information on SAF

When asked about the topics related to the SAF which interest the Slovenian public most, the representatives of the media often opt for the mission and tasks of the SAF in international operations and missions. In second place, they chose assistance to the population in the context of protection and rescue and, in third place, incidents, and, in fourth place, civil-military cooperation. These 
were followed by life and work in the barracks in fifth place, military training and education in sixth place, and military exercises in seventh place.

When asked which topics could benefit from more reporting, the respondents classified all of the above contents in the same order of importance. When asked about the proposals on what the SAF should do, they stated the following:

- In cooperation with Slovenian national television, following the example of other countries, they should provide for broadcasting of documentaries on work and life in the barracks.

- Devote more attention to developing a positive public image.

- Provide the Slovenian public with better information about the use of budget resources, because it is very interested in this.

The evaluation of the employees in the field of public relations according to individual criteria is shown in Figure 2.

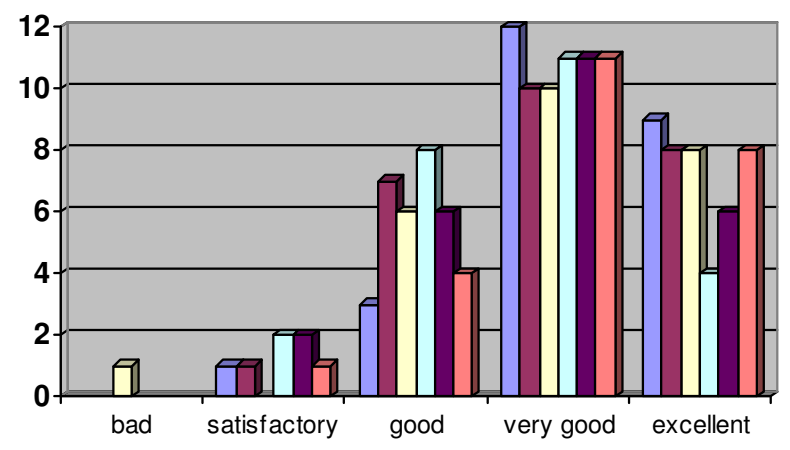

$\square$ personal availability

$\square$ availability

$\square$ responsiveness

$\square$ content quality

a accuracy

$\square$ timely provision

Figure 2: Assessment of the employees in the field of public relations in the SAF

As a primary source for obtaining information on the SAF, media representatives chose different websites. Assessment of the MoD web site is shown in Chart 3. 


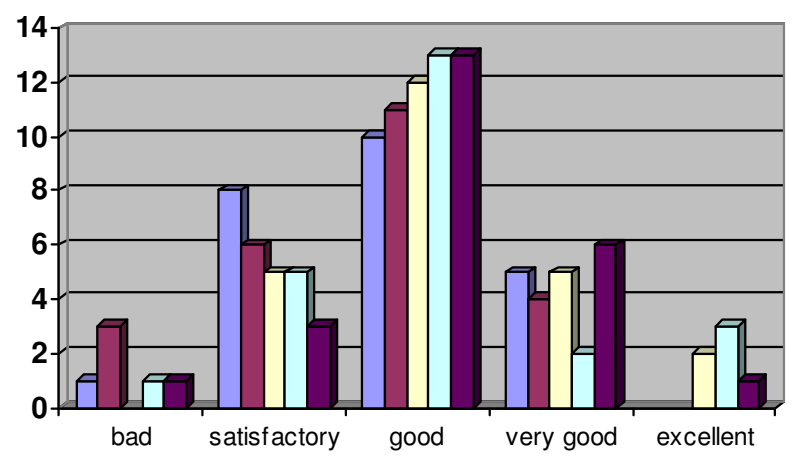

Figure 3: Assessment of quality of MoD's official website

When asked to propose the content to enrich web pages in the open-type section, the respondents suggested that more emphasis should be devoted to the presentation of individuals, for example, commanders, award recipients, units and photo material from international operations and missions.

For the representatives of the Slovenian media, SAF public relations officers occasionally organise visits to SAF members in international operations and missions. We wanted to know how often the sampled media representatives attend such trips.

One such visit was attended by 31 per cent of respondents, two by 38 per cent, 23 per cent attended it several times, but 42 per cent never attended them.

85 per cent of respondents believe that such trips should be organised more often.

\section{Professional and scholarly view on the quality of public relations in the SAF}

The project Public confidence in the SAF was carried out in collaboration with the Obramba magazine. In June 2013, CJM published completely fresh results of public opinion measurement, according to which the SAF was again in the first place considering confidence in public institutions, the same as in January 2013 and in the measurements from previous years. 

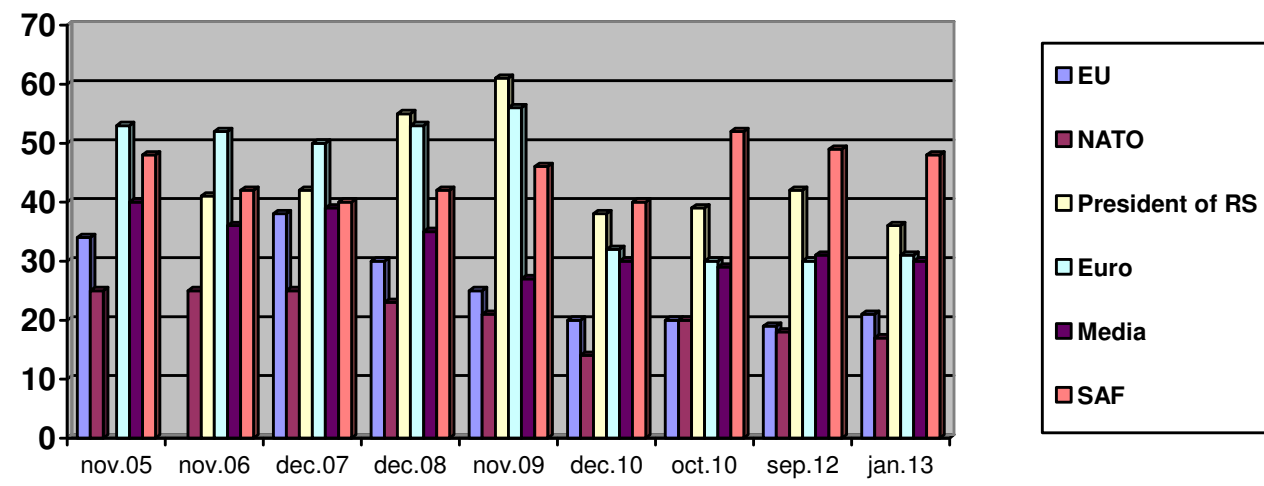

Source: http://www.cjm.si/node, 5 March 2015.

Figure 4: Confidence in some Slovenian institutions according to CJM research outcomes in the period between 2005 and $2013^{11}$

As commented on by Garb (2013, p. 8) ${ }^{12}$, the representatives of the SAF like to pride themselves in public as a trustworthy institution, while remembering that the armed forces in democratic countries normally rank at the top of the charts of public confidence, and this trust is substantially higher ${ }^{13}$ than in Slovenia, where the proportion of confidence is approximately 50 per cent. Only two countries out of 31 demonstrate a lower share than Slovenia.

However, in the national context, Vuga highlights the fact that the public supports the SAF and its operations in MOM, but only as long as everything goes according to plan, until there are no riots, wounded and dead (Vuga, 2013). Brankovič highlighted the fact that the SAF has many experts with specific types of skills that could be shared with the Slovenian public more frequently, but it also has many opportunities, which are not exploited enough. In making this assessment, he relies on the US experience of promoting the armed forces (Brankovič, 2013, p. 10). According to Kocjan, in the public political discourse, the armed forces

11 In 2014, the Slovenian Armed Forces were not included in the measurement of public opinion.

12 Garb based her view on the interviews with SAF chiefs of the General Staff, Major General Alojz Šteiner and Brigadier General Dobran Božič.

13 In 2010, confidence in the armed forces of European countries was as follows: Germany $70 \%$, Greece $67 \%$, France $71 \%$, Italy $65 \%$, Austria $72 \%$, Estonia $80 \%$, Slovakia $72 \%$ and Hungary $57 \%$. 
are frequently considered of no use. It is the first institution to suffer from budget cuts when a public finance crisis occurs, because everything must first be tried out in the military, and sometimes they would just like to abolish the armed forces. From this perspective, a relatively high and constant support for the armed forces is actually a paradox. Kocjan argues that the Slovenian public distinguishes very clearly between what the armed force in its essence actually is, and what political impacts it is subjected to (Kocjan, 2013, p. 11). The power of the SAF lies in its quiet role at the home; only a few are familiar with its activities in international operations and missions, but certainly not those who are interested only in what is going on down their street (Tepina, 2013, p. 12). Krajner was particularly pleased with the experience in the field of public relations. He was a representative of the Pristop agency, which worked with the SAF in the "Ponosni nase (Proud of Ourselves)" media campaign. According to him, those employed in the economic sector can learn from the SAF about how to communicate, since the SAF does not blindly follow trends in communication, but rather forms them (Krajner, 2013, p. 7).

\section{Discussion}

On the basis of the projects, the SAF internal public can be divided into two target groups. The first includes employees with less seniority, i.e. the younger generation, with a contract of employment for a fixed term. They are most interested in their status within the system, their salary and opportunities, how to earn a salary, what their promotion options are, what their further education and training options are for new tasks and opportunities, and especially how to extend the contract. This group builds its professional military career and is interested in everything related to it. The second group includes employees with longer seniority, with employment contracts for an indefinite period and the logic of public servants. Most have higher levels of education; they follow current developments at home and abroad, and want to know more about topical patterns and future developments in the field of security and defence. They feel more connected with the defence system, with more belonging; they are interested in what is happening to other employees at a personal level and want to be active creators of the system's future. 
Irrespective of this, they all want topical and correct information. In the results obtained it is particularly interesting that the employees want to know more about the individuals within the system, rather than the leaders. They are interested in the experience of others on duties abroad, in international operations and missions, in military education and training programmes.

In addition to personal communication, electronic communication and websites are very frequently used tools. It is therefore necessary to devote more attention in the future to such a mode of communication, both in terms of the content as well as in technical terms.

All this was also confirmed in the case of the evaluation of communication with the external public and media representatives. They also mainly use personal communication, but assign equal importance to timely and accurate information online. As demonstrated by the results, the website of the Ministry of Defence for the internal public (Info Point) with an average rating of 2.8 and for the external public with an average rating of 3.0 in a range from 1 to 5 still leave many possibilities and opportunities to provide more extensive and better service to the public.

In the case of media representatives, journalists and scholars, we found that the Slovenian (external) public can be divided into two target groups. The first certainly includes major national media companies and scholars. They are interested in the information about the SAF in general, and especially in the content of strategic importance, such as the financing of the defence system and its expenditure; planning activities in the field of defence and international cooperation, long-term decision-making procedures; planned inputs into the system and future benefits for individuals and particularly for the country. The participants in this group include professionals who are demanding in their expectations and regularly follow the developments; they are analytical and critical in their interpretations. Public relations representatives in the SAF should devote their full attention to them and, thus, be responsive, correct and professional.

The second group includes the local media. These are usually not so much concentrated on the strategic decisions, but are rather interested in the local community and the life in it. The SAF is thus of interest to them in the communities where there are SAF facilities, especially barracks, and its employees are located. 
In those environments, civil-military cooperation and, of course, the fact that SAF employees also form an integral part of the local population and are constantly present there, come to the fore. The local media are interested in the experience of individuals and the specific nature of their profession, the integration of such individuals into the society and similar sociological issues.

Garb's comment on the comparison of the general public's confidence in the SAF with the confidence in the armed forces of other countries does not change the fact that the SAF appears as the first among other state institutions in Slovenia when it comes to confidence. For the latter, we did not look for comparative data in other countries. For our final assessment, it is also important to know the proportion of those who do not trust the SAF. Even considering this criterion, the SAF comes first - with the smallest share.

\section{Conclusion}

The portion of employees with longer seniority expresses similar views and aspirations in the field of public relations as the general Slovenian public. They are cautious; they wish to be informed and to help shape its future as an integral part of the Slovenian public and the defence system. They are interested in strategic decisions and developments in the armed forces in the international environment, and the integration of the SAF in the general social environment. They are critical, just as the representatives of major media companies, which specialise in the field of defence or the national security system.

On the other hand, we have a younger generation of employees who understand the military strictly professionally, knowing why they came into the system, what they want and how they will achieve this. They demonstrate this both in the SAF, as well as in the domestic environment. This was established by Tepina and Kocjan, and they defined it themselves in the questionnaires they received.

Table 2 summarises the main findings of the evaluation in relation to individual publics and projects, which are also the target groups for communication. Some of the findings have regularly been taken into account in our work. We enhanced the SAF's presence on social networks and, thus, reached out to a younger 
generation pertaining to both internal and external publics. So we indirectly avoided administrative, security and IT obstacles that prevented more dynamic communication through the official websites of the SAF and the MoD.

The more demanding tasks for future communication certainly include topical and strategic content where demand exceeds supply.

In the SAF, there is enough knowledge and experience. In the future, we will have to find additional ways to encourage the emergence of written, photographic and audio materials. All this is related to the human and financial resources needed for various forms of training, acquisition of technical and IT equipment and the organisation of various events of public interest.

\begin{tabular}{|c|c|c|}
\hline $\begin{array}{l}\text { Approaches } \\
\text { to evaluation } \\
\text { according to } \\
\text { Rühl }\end{array}$ & Internal public & External public \\
\hline Lay & $\begin{array}{l}\text { The internal web portal Info Point: } \\
\text { - Improve the overall image of the } \\
\text { portal } \\
\text { - Update news } \\
\text { - Improve quality with the proposed } \\
\text { content }\end{array}$ & $\begin{array}{l}\text { Public confidence in the SAF: } \\
\text { - Improve MoD website } \\
\text { - Improve the quantity and quality of } \\
\text { audio and video recordings }\end{array}$ \\
\hline Professional & $\begin{array}{l}\text { SAF's communication with the internal } \\
\text { public: } \\
\text { - Improve personal communication } \\
\text { - Improvethequalityofcommunication } \\
\text { with the proposed contents } \\
\text { - Comment on topical issues of SAF } \\
\text { appearing in public, } \\
\text { - Offer more strategic topics } \\
\text { - Improve the dynamic of SAF } \\
\text { publications/newsletters. }\end{array}$ & $\begin{array}{l}\text { SAF's communication with media } \\
\text { representatives : } \\
\text { - Improve SAF website. } \\
\text { - Improve the quality and quantity of } \\
\text { audio and video recordings. } \\
\text { - Devote more attention to the local } \\
\text { media. } \\
\text { Public confidence in the SAF: } \\
\text { - Connect sporting and charity events } \\
\text { more with the public and invite the } \\
\text { media. } \\
\text { - Events organised by professional } \\
\text { circles should include experts from } \\
\text { the SAF. }\end{array}$ \\
\hline Scholarly & & $\begin{array}{l}\text { Public confidence in the SAF: } \\
\text { - Events organised by scholars and } \\
\text { other professional circles should } \\
\text { include experts from the SAF. }\end{array}$ \\
\hline
\end{tabular}

Table 2: Approaches to evaluation according to Rühl, in connection with individual public relations projects carried out in the $S A F$, and proposed improvements 
So, how good is the quality of public relations in the Slovenian Armed Forces? Considering the circumstances presented by Garb and Vuga, and taking into account the Slovenian public confidence in other state institutions, we can only conclude that it is certainly at a very high level.

The prize for the media campaign only confirms that. Media representatives are relatively satisfied with SAF public relations representatives. Proposals and initiatives came both from the external and internal public. The options for improving the quality of communication are still many.

The results taken into account in this evaluation occurred in the last three and a half years and show the situation as it was in the past. However, the findings of each evaluation are an imperative for the future - the reduction of resources in all areas of state operation, reduction of the defence budget, public sector salaries, number of employees, and, of course, the attitude of the Slovenian public towards the SAF.

In the future, we will continue to look for creative solutions. Unfortunately, the slogan "less is more" is obsolete and there will come a time when it is necessary to say that it is no longer true.

There are still many challenges in the field of public relations in the SAF. Some novelties were suggested by the employees, some by others who participated in the evaluation, but most of them will occur as we go along. And the Slovenian public will once again be the ones to say whom and how much they trust.

\section{Bibliography}

1. Bennet, J., 2003. EVALUATION METHODS IN RESEARCH. London, New York: Continuum Research Methods.

2. Brankovič, J., 2013. SMO DANES RES ZASLUŽILI 1,08 MILIJONA? (Have we really earned 1.8 million today?) »Revija Obramba« (Defence Magazine), July 2013, p. 10.

3. Edmonds, M.,1988. ARMED SERVICES AND SOCIETY.

4. Garb, M., 2013. JAVNO MNENJE O SLOVENSKI VOJSKI DOBRO, A V MEDNARODNO PRIMERJALNI LUČI SLABŠE. (Public opinion on the Slovenian Armed forces is good, but worse if compared to the intenational sphere) »Revija Obramba« (Defence Magazine), July 2013, p. 8. 
5. Hallahan, K., Holtzhausen, D., Van Ruler, B., Verčič, D., Sriramesh, K., 2008. TEORIJA IN PRAKSA (Theory and Practice), 6/2008, pp. 628-662.

6. Huntington, S. P., 1957. THE SOLDIER AND THE STATE, THE THEORY AND POLITICS OF CIVIL-MILITARY RELATIONS.

7. Jelušič, L.,2003. SLOVENIAN PUBLIC OPINION ON SECURITY, DEFENCE AND MILITARY ISSUES. V Marie Vlachova (ed.). THE PUBLIC IMAGE OF DEFENCE AND THE MILITARY IN CENTRAL AND EASTERN EUROPE, pp. 182-200. Geneva: Centre for the Democratic Control of the Armed Forces (DCAF): Belgrade: Centre for Civi-l Military Relations (CCMR).

8. Kocjan, A., 2013. AMBASADORJI SI NE MOREJO PRIVOŠČITI KIKSOV. (Ambassadors cannot afford mistakes.) »Revija Obramba«, July 2013, p. 11.

9. Korez, S., 2008. SLOVENSKA VOJSKA KOT SKUPNOST IN NJENO KOMUNICIRANJE Z JAVNOSTJO. (Slovenian Armed Forces and its public communication) Specialist thesis. Faculty of Social Work, Ljubljana.

10. Krajner, A., 2013. TISTI, KI SMO ZAPOSLENI V GOSPODARSTVU, SE LAHKO UČIMO OD KOMUNICIRANJA SLOVENSKE VOJSKE. (Those of us employed in the economy sector can learn from the communication of the Slovenian Armed Forces) »Revija Obramba« (Defence Magazine), July 2013, p. 7.

11. Prezelj, I., 1997. KOMUNICIRANJEMED OBOROŽENIMI SILAMIINJAVNOSTMI. (Communication between armed forces and publics) Teorija in praksa (Theory and Practice) XXXIV (6): pp. 1020-1034.

12. Rihter, L. 2004. EVALVACIJE NA PODROČJU SOCIALNEGA VARSTVA IN NJIHOV POMEN ZA PRILAGAJANJE SODOBNIH DRŽAV BLAGINJE NA IZZIVE GLOBALIZACIJE. (Evaluations in the field of social protection and their importance for the adjustment of modern welfare states to globalisation challenges). Doktorska disertacija. Ljubljana 2004, pp 83-137.

13. Rühl, M., 2008. PUBLIC RELATIONS METHODOLOGY SHOULD WE BOTHER (IF IT EXISTS)?. V van Ruler, Betteke; Tkalac Verčič, Ana; Verčič, Dejan, PUBLIC RELATIONS METRICS RESEARCH AND EVALUATION.

14. Rus, V., Toš, N., 2005. VREDNOTE SLOVENCEV IN EVROPEJCEV, ANALIZA VREDNOTNIH ORIENTACIJ SLOVENCEV OB KONCU STOLETJA. (Values of Slovenians and Europeans - analysis of value orientation of Slovenians at the end of the century) Faculty of Social Sciences. IDV, CJMMK, pp. 333-369.

15. Serajnik Sraka, N., 2008. VREDNOTENJE V ODNOSIH Z JAVNOSTMI. (Evaluation in public relations) Teorija in praksa (Theory and Practice), 6/2008, pp. 870-876.

16. Tepina, J., 2013. TUDI ČE SI NAJMANJŠI, NI TREBA, DA GOVORIŠ, KAKO SI DOBER, DA LJUDJE TO PREPOZNAJO. (Even if you are the smallest, you do not have to state how good you are in order to be recognised.) »Revija Obramba« (Defence Magazine), July 2013, p. 12. 
17. Van Dyk, M., Verćič, D., 2009. PUBLIC RELATIONS, PUBLIC DIPLOMACY AND STRATEGIC COMMUNICATION: AN INTERNATIONAL MODEL OF CONCEPTUAL CONVERGENCE. V Sriramesh, Krishnamurty, Verčič (ed.): THE GLOBAL PUBLIC RELATIONS HANDBOOK REVISED EDITION: THEORY, RESEARCH, AND PRACTISE, pp. 822-842.

18. Verčič, D., 1995. ODNOSI ZJAVNOSTMI: NASTANEK, ZGODOVINA IN TEORIJE. (Public relations: emergence, history and theories) Master's thesis.

19. Verčič, D., 1999. ODNOSI Z JAVNOSTMI V EVROPI. (Public relations in Europe)

20. Vuga, J., 2013. SPREJEMLJIVOST MEDNARODNIH OPERACIJ IN MISIJ DOKLER NE POSTANE »VROČE«. (Acceptability of international operations and missions until it gets dangerous.) »Revija Obramba« (Defence Magazine), July 2013, p. 9. 